\title{
Corporate Social Responsibility REPORTS: A REVIEW OF THE Recent AcCounting Literature
}

\author{
Michael 7. Fischer and Carol M. Fischer
}

Michael J. Fischer (mfischer@sbu.edu) and Carol M. Fischer (cfischer@sbu.edu) are both Professors of Accounting in the School of Business, St. Bonaventure University, St. Bonaventure, NY 14778. Correspondence concerning this paper may be directed to Michael J. Fischer.

\begin{abstract}
Concerns regarding corporate social responsibility (CSR) have been present for many years and have fostered a mature and rich literature. In more recent years there have also been significant developments in the area of CSR reporting. Examples include the dissemination of such concepts as the "triple bottom line;" the development and promulgation of standards by various international groups; and the creation of the Sustainability Accounting Standards Board (SASB) in the United States.

Recent evidence indicates that CSR information is increasingly seen by investors as being a valuable supplement to traditional financial statements, and that the U.S. Securities and Exchange Commission
\end{abstract}


74 The BRC Academy Journal of Business Vol. 7, No. 1

(SEC) is evaluating the need for expanded disclosure requirements. This is a rapidly developing area in the overall financial reporting arena. However, the extent that recent accounting research has addressed this area is not clear.

This paper reports on an examination that was undertaken of the publications regarding CSR reporting in twelve mainstream accounting journals during the period from 2010 to 2015. A summary of the recent accounting literature regarding CSR reports is provided. There appear to be numerous opportunities for contributions by accounting scholars across the full range of basic, applied, and instructional scholarship.

Keywords: corporate social responsibility reports, sustainability, environment, assurance, integrated reporting

DOI: http://dx.doi.org/10.15239/j.brcacadjb.2017.07.01.ja04

\section{INTRODUCTION}

Corporate social responsibility $(\mathrm{CSR})^{1}$ has attracted a great deal of attention in both the academic and practitioner business literatures for many years. While no single, generally agreed-upon definition of CSR yet exists (on this point, see e.g., Sheehy, 2015), the following seems to capture many of the important elements; corporate social responsibility reflects:

A company's commitment to operating in a socially, economically and environmentally sustainable manner, while recognizing the interests of its stakeholders. (PwC, 2010, p. 51)

Systematic CSR reporting has not been in existence for as long as business researchers have engaged in general discussions regarding corporate social responsibility. Nevertheless, CSR reports have been issued by a variety of companies for some time. Regarding the prevalence of CSR reporting, PwC indicated in 2010 that "CSR reports are becoming an integral part of a company's relationship with employees, suppliers, customers, investors and communities" (p. 2), and reported that $81 \%$ of 
the 423 companies they studied had CSR information on their websites (p. 3). Similarly, by 2013 KPMG indicated in its Survey of Corporate Responsibility Reporting that "the debate on whether companies should report on CR [Corporate Responsibility] is dead and buried" and "in the $21^{\text {st }}$ century, CR reporting is - or should be - an essential management tool” (p. 9). In that same report, KPMG defined CR reporting as:

the process by which a company can gather and analyze the data it needs to create long term value and resilience to environmental and social change. CR reporting is essential to convince investors that your business has a future beyond the next quarter or the next year. (2013, p. 9)

Publications calling for and describing CSR and related types of disclosures have been emerging in recent years. Perhaps among the most recognized, at least for its title, is The Triple Bottom Line published by Savitz and Weber in 2006. The triple bottom line is built around the concept of "sustainability" and calls for companies to report on (and actively manage) their economic, environmental, and social performance.

There have also been increasing efforts in recent years to develop and promulgate standards for this type of reporting. The Global Reporting Initiative (GRI) has published guidelines and standards for sustainability reporting. Four generations of the GRI "guidelines" have been published, with version G4 issued in 2013. The GRI issued its first set of "standards" in 2016. The Social Accountability Standards Board (SASB) was formed in the U.S. as an independent 501(c) (3) corporation in 2011 "to develop reporting standards and benchmarks for environmental, social and governance issues" (Verschoor, 2012, p. 13). As of March 2016, the SASB had completed issuance of its first full set of provisional standards for 79 industries in 10 sectors (SASB, 2016).

Related developments have also occurred in the area of integrated reporting. Early works calling for an integrated approach have included The ValueReporting Revolution (Eccles, et al., 2001), and more recently One Report: Integrated Reporting for a Sustainable Strategy (Eccles and 
Kruzus, 2011) and The Integrated Reporting Movement (Eccles and Kruzus, 2015). The International Integrated Reporting Council (IIRC) was formed to develop a global framework for integrated reporting, with a vision "to align capital allocation and corporate behavior to wider goals of financial stability and sustainable development through the cycle of integrated reporting and thinking" (IIRC, 2016). The IIRC first disseminated its International $<\mathrm{IR}>$ Framework in 2013.

Various standards have also been developed for assurance services on CSR reports. For example, the International Auditing and Assurance Standards Board (IAASB) issued International Standard on Assurance Engagements (ISAE) 3000, Assurance Engagements Other Than Audits or Reviews of Historical Financial Statements in 2003. In the U.S. "the AICPA Attestation Standards (AT Section 101) allow CSR assurance engagements in certain circumstances, including when the practitioner has adequate knowledge of the subject matter and reason to believe that the subject matter is capable of evaluation against criteria that are both available and reliable to a user" (Lynch, 2013, p. 35).

Given the apparently accelerating developments in this area in recent years, reflected in the significant growth in rates of CSR reporting and the ongoing efforts to develop guiding standards, it would seem reasonable to ask whether this phenomenon has been subjected to study by accounting researchers, and what we have learned about CSR reports from their publications. This paper reports on a review of the recent accounting literature undertaken to answer these questions.

The following section of this paper presents an overview of the method employed in conducting the literature review as well as a summary of the papers reviewed; the final section then provides a summary and conclusions. 


\section{Research Method And Findings}

An examination was undertaken of the contents of twelve leading accounting journals for the period from 2010 to 2015. CSR reporting is a relatively recent phenomenon that has been experiencing significant growth in practice. Although there certainly were publications on this topic prior to 2010, this relatively short window for examination was chosen in an effort to assess the current literature in this rapidlydeveloping area.

The journals selected for examination are indicated in Figure 2. These journals publish articles spanning the spectrum of basic, applied and instructional scholarship. Articles addressing CSR reporting have been published in other outlets, but these particular journals were selected as representing the "mainstream" of accounting publications across these multiple categories of scholarship. The contents of each issue of the twelve journals published during the indicated time period were reviewed. All articles dealing with CSR reports and reporting ${ }^{2}$, including assurance of those reports, were selected for examination. As indicated in Figure 2, a total of 35 articles dealing with these topics were identified.

Each identified article was reviewed. A simple schema for categorization of the articles was then developed by the authors after all the articles were initially read. Each article was then sorted into one of the following five categories:

1. Conceptual: CSR Reports and Reporting

2. Conceptual: CSR Assurance Services

3. Empirical: CSR Assurance Services

4. Empirical: Correlates of CSR Reporting

5. Empirical: Examination of CSR Reports

Figure 3a presents a listing of the 35 articles sorted into these five categories; Figure $3 \mathrm{~b}$ then provides a graphical depiction of the distribution 
of articles across the category. The remainder of this section provides an overview of the articles in each category.

\section{CONCE PTUAL: CSR Reports AND REPORTING}

This is the largest single category of publications during the time period examined. However, many of the articles were relatively short. These papers were further judgmentally grouped into a total of three subcategories for purposes of this review: (a) those providing overviews of CSR reporting; (b) articles addressing technical aspects of CSR reporting; and, (c) those providing academic literature reviews or proposed research frameworks. Each of these three sub-categories is briefly summarized in the remainder of this section.

\section{Articles providing overviews of CSR reporting}

Interestingly, all of the identified articles providing general overviews of CSR and integrated reporting were published in Strategic Finance. Drawing heavily on the 2011 KPMG International Survey of Corporate Responsibility Reporting, Verschoor (2012) provided an overview of the growth in rates of CSR reporting, as well as brief summaries of the various standards for such reporting then under development or in place. Verschoor cited the lack of standardization to-date as an impediment to further growth in and reliance on CSR reports (p. 13). A series of three articles were then published on the related topic of integrated reporting (Monterio, 2014, 2015; Dzinkowski, 2015). All three of these articles included descriptions of standards for integrated reporting, with the focus largely on the International Integrated Reporting Council's (IIRC) Integrated Reporting (IR) framework. In the Dzinkowski article, IR is described as "a vision of corporate reporting that brings together, in an integrated fashion, key nonfinancial performance indicators and value drivers, including a company's efforts and impacts related to corporate responsibility and sustainability development" (p. 41). All of the authors argued for the future of integrated reporting and the need for generally 
accepted standards. Dzinkowski also described the formation of the Sustainability Accounting Standards Board (SASB) and their mission to "develop one set of rigorous standards for sustainability disclosure that will be widely accepted and used consistently by U.S. public companies in their SEC filings" (2015, p. 43; italics in original).

\section{Articles addressing technical aspects of CSR reporting}

A total of five papers were published in the time frame under study that addressed technical aspects of CSR reporting. In 2011, the fournal of Accountancy published an article by Fornaro that provided an overview of the then-new SEC guidance on disclosures related to climate change. Strategic Finance published a series of articles by Monterio (2010 a \& b; 2013) that described ways in which XBRL capabilities could be used in implementing CSR reporting systems. Finally, an article by Thomas (2015), drawing on work done by the SASB, describing the value of key performance indicators in CSR reporting was published in Strategic Finance.

\section{Articles providing literature reviews or research frameworks}

A total of four papers were grouped into this sub-category. Unerman and Chapman reported on their review of the literature on accounting and reporting for sustainable development in a 2014 Accounting, Organizations and Society article. They identified what they considered to be three broad strands in the literature: one seeking "to demonstrate relationships between social and environmental performance, social and environmental reporting, and economic performance;" a second, suggesting "that social and environmental unsustainability is largely a consequence of the capitalist system and that the best (or only) way to move towards a socially and ecologically sustainable system is to radically reform or even overthrow markets and capitalism;" and, a third strand that "seeks to constructively engage with businesses and other organizations to help them identify a range of social and environmental sustainability risks and make changes to the way they operate in a direction intended to result 
in less unsustainable operations" (p. 385). They then focus on further review of the third strand of literature.

A second review of the academic literature was published in the fournal of Accounting Literature in 2015 by Huang and Watson based upon a review of 47 papers published in thirteen top accounting journals from 2004 through 2015. Through their review, they identified four segments of the literature: (1) determinants of CSR; (2) the relation between CSR and financial performance; (3) consequences of CSR; and (4) the roles of CSR disclosure and assurance (p. 1). However, they identified little prior literature that reported the details from direct examination of CSR reports. In fact, they indicate that "compared to research on the existence or quantity of CSR disclosure, research on CSR disclosure quality is quite limited" (p. 11; italics in original).

In a 2012 article in The Accounting Review, Moser and Martin argued for a "broader perspective" on CSR reporting research, particularly through the use of experimental studies as a complement to those undertaken using archival methodologies. Based on their review of the literature, they indicate that "despite a significant amount of prior research, we do not yet fully understand the extent to which certain CSR disclosures are directed toward investors, other stakeholders, or both. Nor do we fully understand how investors and other stakeholders react to CSR disclosures. Further, without understanding managers' incentives for disclosing CSR information, we are unsure whether such disclosures are reliable" (p. 801). They go on to argue that "archival CSR studies alone are unlikely to provide us with a full understanding of the motivations for, and consequences of, CSR activities and managers' related disclosure choices. Consequently, we suggest that controlled experiments be used to address important CSR issues that are difficult to address effectively in archival studies" (p. 802). They then provide a summary of CSR reporting research performed to date using experimental methodologies and offer recommendations for future research. 
In the final paper in this sub-category, Ramanna (2013) applied agency and positive accounting theories to derive a set of hypotheses to distinguish between explanations for CSR reporting and then offered suggestions for the empirical testing of these hypotheses. Ramanna suggested that CSR reporting should be an area of greater focus by accounting researchers since it is a growing phenomenon and because "accounting researchers have a comparative advantage in studying corporate accountability reporting" (p. 411).

\section{Conce ptual: CSR Assurance Services}

There are several papers that explore the topic of CSR assurance services at a conceptual level. First, in a fournal of Accountancy article in 2013, Lynch provided an overview of the growth in the prevalence of independent assurance reports accompanying CSR reports, the share of the assurance market held by accounting firms (approximately $52 \%$ in 2012), and standards regarding independent assurance service examinations and reporting.

Two conceptual articles regarding CSR assurance services were published by Cohen and Simnett in 2015. The first (2015a) was a lead-in to a forum on CSR and assurance services in Auditing: A fournal of Practice \& Theory; and, the second article (2015b) was their own contribution to that forum. The latter article provided a description of the current environment for assurance services on CSR reports, articulated opportunities for research regarding CSR assurance services, and concluded with an overview of the other papers in the forum. Like Lynch, Cohen and Simnett identified significant growth in the rates of CSR reporting, independent assurance of those reports, and assurance services being provided by accounting firms (2015, pp. 59-60). However, they also indicated that "little is known about the best-practices for conducting a high-quality assurance engagement” of CSR reports (2015, p. 62). 


\section{Empirical: CSR Assurance Services}

A total of six papers were identified that reported on a variety of empirical studies of CSR assurance services. Two very different articles in 2011 were the first to be published in this category during the examined time period.

Pflugrath, et al. (2011) reported on a behavioral experiment with financial analysts in Australia, the United States, and the United Kingdom as subjects. The research instrument included selected financial and CSR information, as well as assurance reports, for two fictitious companies. The research results indicated that "the credibility of a CSR report is greater when it is assured and when the assurer is a professional accountant" (2011, p. 239).

O'Dwyer, et al. (2011) published the results of a field study examining the processes of legitimating CSR assurance services in a Big 4 firm in Europe. In motivating their study, the authors cited a "...trend in academic auditing research in which direct engagements with practitioners (assurers) seeking out their perspectives on their work and its evolution remain relatively rare" (2011, p. 32). In this particular study, however, the authors focus on the social processes surrounding CSR assurance services, rather than on the conduct of CSR assurance engagements.

The other four papers in this category were all published in the 2015 Auditing: A fournal of Practice \& Theory forum on CSR and assurance services mentioned in the preceding section. Casey and Grenier (2015) examined what they described as the "enigma" of CSR assurance (CSRA) services in the US: that the level of voluntary assurance sought by US firms significantly lags that of their international counterparts. Through their study, they "find that CSRA is associated with a reduction in the cost-of-capital along with lower analyst forecast errors and dispersion" ( $p$. 100). They concluded by stating that "our results suggest that the scarcity of CSRA in the U.S. is puzzling, as it is reasonable to speculate that many U.S. firms would benefit from CSRA, but are currently not obtaining 
it" (p. 100). Their methodology did not involve the direct examination of either CSR or CSRA reports; rather just whether those reports were or weren't issued by the examined firms.

Brown-Liburd and Zamora, and Cheng, et al. both reported on the results of experiments examining the impact of CSR report assurance on various other factors. In an experiment involving investors, BrownLiburd and Zamora (2015) examined "the role of CSR assurance when information on CSR investment level is integrated with information on whether managerial pay is explicitly tied to sustainability" (p. 75). They reported their finding that "in the presence of pay-for-CSR performance and high CSR investment level, investors' stock price assessments are greater only when CSR assurance is also present” (p. 75). Based on an experiment involving graduate students in a financial analysis course, Cheng, et al. (2015) found that "investors perceive ESG [Environmental, Social, and Governance] indicators to be more important, and are more willing to invest in the company if ESG indicators have higher strategic relevance. [The results] also provide evidence that assurance increases investors' willingness to invest to a greater extent when ESG indicators have high relevance to the company's strategy...[and that] the assurance of ESG indicators has a beneficial signaling role in communicating the importance of this reported information to investors" (p. 131). Both experiments used simulated CSR report materials developed based on actual reports; neither paper included the report materials used.

Finally in this category, Peters and Romi (2015) used archival information to examine whether the presence and characteristics of a Board of Directors' sustainability committee and a Chief Sustainability Officer (CSO) impact the voluntary assurance of corporate sustainability reports. Based on their study they report that (1) "the presence of a CSO is positively associated with corporate sustainability report assurance services, and that this association increases when the CSO has sustainability expertise" (p. 163); (2) "only those environmental committees containing directors with greater expertise influence the likelihood of obtaining 
assurance services" (p. 163); and, (3) "environmental committees with greater expertise appear to prefer the higher-quality assurance services of professional accounting firms. Expert CSOs, on the other hand, prefer assurance services from their peers with sustainability expertise" (p. 163). Assurance reports were apparently not examined in any detail in this study; rather, just the presence or absence of a report and the nature of the provider were noted.

\section{EMPIRICAL: CoRrelates OF CSR REPORTING}

There were eight papers published during the time period that empirically examined various correlates of CSR reporting. Two of the studies were by Dhaliwal and co-authors. Dhaliwal, et al. (2011) reported their findings that "firms with a high cost of capital in the previous year tend to initiate disclosure of CSR activities in the current year and that initiating firms with superior social responsibility performance enjoy a subsequent reduction in the cost of equity capital. Further, initiating firms with superior social responsibility performance attract dedicated institutional investors and analyst coverage. Moreover, these analysts achieve lower analyst forecast errors and dispersion” (p. 59). Dhaliwal, et al. (2012) reported that "the issuance of stand-alone CSR reports is associated with lower analyst forecast error" (p. 723). There was no detailed examination of the contents of CSR reports in either of these studies; rather, CSR reporting was operationalized as just the presence or absence of a report.

Kim, et al. (2012) conducted a study to determine whether socially responsible firms behave differently from other firms in their financial reporting. They report that "socially responsible firms are less likely to (1) manage earnings through discretionary accruals, (2) manipulate real operating activities, and (3) be the subject of SEC investigations" (p. 761). Extent of social responsibility of the examined firms was based on third-party evaluations conducted and published by Kinder, Lydenberg, Domini Research and Analytics (KLD). No direct examination of CSR reports was performed by the researchers. 
Gao, et al. (2014) also employed KLD ratings to operationalize firm commitment to social good in their study. They reported that "the executives of CSR-conscious firms profit significantly less from insider trades and are less likely to trade prior to future news than executives of nonCSR-conscious firms" (p. 150); thus, firm corporate social responsibility appears to carry over to the behavior of its managers as well. As with the previous studies reviewed in this section, there was no review of actual CSR reports conducted or reported.

Elliott, et al. (2014) studied the effect of CSR performance on investors' estimates of value based upon an experiment conducted with MBA students serving as proxies for investors. The experimental materials included simulated CSR disclosures. Based on their study, the authors reported that "investors who are exposed to, but do not directly assess, CSR performance, derive higher fundamental value estimates in response to positive CSR performance, and lower fundamental value estimates in response to negative CSR performance. Explicit assessment of CSR performance, however, significantly diminishes this effect” (p. 275).

Next in this set of studies are two papers by Cho and co-authors. In 2010, Cho, et al. published an article examining "whether there are self-serving biases present in the language and verbal tone used in corporations' environmental disclosures" (p. 431). They performed content analysis of the environmental disclosures contained in the 10 -K reports of 43 U.S. companies, and found evidence of the hypothesized self-serving biases (p. 431). Cho, et al. (2012) then investigated "the extent to which firms' environmental performance is reflected in perceptions of their environmental reputation and whether environmental disclosure serves to mediate the negative aspects of poorer environmental performance" ( $\mathrm{p}$. 14), reporting that "voluntary environmental disclosure appears to mediate the effect of poor environmental performance on environmental reputation" (p. 14). In a significant departure from the methodology employed in most of the other papers in this category, the authors operationalized extent of disclosure using a 95-point index in their 
examination of the actual CSR disclosures made by the 92 US firms in their sample.

Finally in this category, Lys, et al. (2015) published their findings that "CSR expenditures are not a form of corporate charity nor do they improve future financial performance. Rather, firms undertake CSR expenditures in the current period when they anticipate stronger future financial performance...[therefore CSR reporting] is another channel through which outsiders may infer insiders' private information about firms' future financial prospects" (p. 56).

\section{EMPIRICAL: EXAMINATION OF CSR REPORTS}

Finally, there were a total of five articles during the time frame studied that empirically examined CSR reports as the primary phenomenon of interest rather than as an independent variable. Three of the articles were published in the practitioner-oriented Strategic Finance, and the other two appeared in the academic-focused Accounting, Organizations and Society.

In 2010, Borkowski, et al. published in Strategic Finance the results of a case study of sustainability reporting by Johnson \& Johnson (J\&J). The study involved the content analysis of sustainability reports published by J\&J from 1993 through 2008 as well as interviews with executives. The article included comparative summaries of the analysis of the report contents along various dimensions. In 2014, Busco, et al. published an article in Strategic Finance that provided an overview of the IIRC's Integrated Reporting (IR) framework. The article also provided a detailed overview of the most recent integrated reports published by four different companies involved in piloting the IR framework. Finally, later in 2014 Strategic Finance published an article by Verschoor that provided an overview of the current state of IR as well as a relatively brief overview of the 2014 Clorox Corp. integrated report. In the article Verschoor indicated that "the movement to address stakeholders beyond investors is gaining strength, but (in the U.S.) it still lags behind other countries" (pp. 13-14). 
The final two papers in this category were both published in Accounting, Organizations and Society in 2014. Tregida, et al. (2014) investigated how organizations represented themselves relative to sustainable development in 365 publicly available CSR reports issued by 47 different organizations between 1992 and 2010. The analysis indicates that organizational identities as represented by the CSR reports tend to change over time, and that the identities portrayed tend to be of three distinct types: environmentally responsible and compliant organizations; leaders in sustainability; and, strategically "good" organizations (p. 477). Taking a different approach, Contrafatto (2014) reported on a prolonged field study of the organizational dynamics that began with the introduction of social and environmental reporting (SER) in a single Italian company. The results indicate a three-step process through which SER came to be institutionalized in this organization: "(i) the construction of a common meaning system around the concept of social and environmental responsibility; (ii) practicalisation involving the emergence of rules and routines; and (iii) reinforcement through the implementation of inter-organizational managerial procedures and structures" (p. 414). Neither of these articles reported any details of the CSR reports issued by the studied companies.

\section{Summary And Conclusions}

The preceding section has provided a summary of the 35 papers published during the period from 2010 through 2015 on the topic of CSR reporting in the twelve journals selected for examination. There are limitations of the study reported here. The most obvious limitations relate to the time period and individual journals selected for review. There are papers on the topic of CSR reporting that were published prior to 2010. Similarly, there have been many publications on this topic in journals other than the twelve that were selected as the focus of this study; for example, such other accounting journals as Sustainability Accounting, Management and Policy fournal and Social and Environmental Accountability fournal, and such non-accounting journals as fournal of Business Ethics and Business \& 
Society have published papers examining various aspects of CSR reports and reporting. However, the intent of this study was not to provide an exhaustive review of the literature, but rather just an overview of the most recent publications in what might be considered "mainstream" academic and practitioner accounting journals.

The limitations notwithstanding, the study reported here provides significant insights into the nature of recent accounting publications regarding CSR reports and reporting. Many of the reviewed papers cite this as an area of growing interest and importance for both accounting practitioners and academics. However, this is also a rapidly evolving area. The depth and diversity of knowledge regarding CRS reports and reporting is at a much earlier stage than that of traditional financial reporting. Rather than well-established, "generally accepted" standards as is the case with financial accounting and reporting, there are a variety of different standards for CSR and related types of reporting, none of which are yet authoritative, even in a single country such as the U.S. And, rather than being required like financial reporting, CSR reporting is still largely voluntary.

The publications reviewed provide clear evidence of the apparent benefits of voluntary CSR reporting, as well as of obtaining independent assurance on the issued reports. For example, the research indicates that among the apparent benefits of voluntary CSR reporting are reduced cost of capital, greater levels of analyst coverage, and reduced analyst forecast error. Similarly, research suggests that voluntary assurance on CSR reports increases the credibility of the reports, and is associated with reduced cost of capital and lower analyst forecast errors. However, unlike the literature on traditional financial reporting, the research on impacts of CSR reporting and assurance is less mature, and there appear to be considerable opportunities for further research. For example, this literature could be meaningfully advanced through research that seeks to replicate, and assess the robustness of, the results of the small body 
of existing studies across different sets of companies, industries and time periods.

Further, most of the empirical studies that have been published have employed very simple proxy measures, e.g., the presence or absence of a published CSR report or assurance report. There would appear to be great potential for enhancing understanding through the use of more granular measures. For example, the impact of the extent of CSR disclosure or the disclosure standards followed on such outcomes as cost of capital and analyst forecast error could be studied. Similarly, the effect of assurer choice (e.g., Big 4 CPA firm or other assurer) or assurance standards applied on these same outcomes could be examined.

Performing such finer-grained studies will be facilitated by a detailed understanding of existing practices in CSR reporting and assurance. However, at least in the last six years in the twelve journals reviewed, there has been relatively little information published regarding the contents of actual CSR reports or CSR assurance reports. Rather, the articles that have reported on the examination of actual CSR reports have tended to be limited case studies of one or several companies, and have tended to present just relatively brief overviews of the disclosures. Further, there were no published articles that reported on the detailed examination of CSR assurance reports or examinations.

There appear to be very significant opportunities for descriptive studies that report on detailed examination of actual CSR reports and related independent assurance reports. Examples of a few of the questions that could be examined through such descriptive studies are:

- Who are, and what are the characteristics of, the companies that are voluntarily issuing CSR reports?

- Where is this information reported (e.g., in stand-alone reports, or integrated with financial reporting information such as the Form $10-\mathrm{K})$ ?

- What is the content of published CSR reports? 
- What is the manner in which information is presented (e.g, are KPIs or other metrics used)?

- What standards, if any, are followed in preparing the reports?

- Is there an "auditor effect" (e.g., are the financial statement audit clients of particular firms more likely to report, or to report in different manners)?

- What are the characteristics of companies that issue CSR assurance reports?

- What are the contents of published CSR assurance reports?

- What standards, if any, are followed in the published CSR assurance reports, and in the underlying CSR assurance examinations?

In addition to providing descriptive information that will be valuable in its own right, the insights gathered through such studies would also be beneficial to scholars undertaking research into the correlates of CSR reports and CSR assurance reports, who to-date appear to have relied almost exclusively on very simple proxy measures (e.g., presence or absence of a report).

After a richer understanding of CSR reports and reporting has been developed through descriptive research to answer questions such as those posed above, there would then appear to be significant opportunities for developing an understanding of what the reports are telling us about companies' socially responsible behavior; this level of understanding appears to be currently almost non-existent, at least in the mainstream accounting literature. Similarly, there appears to be very little in the literature examining how published CSR information is used; for example, by owners and other stakeholders, analysts, prospective investors, and regulators.

Another area of research opportunity, particularly after a richer understanding of the reporting behavior itself has been developed, involves manager choice. A few such relevant questions are: why do firm managers choose to engage in this costly reporting and assurance behavior; and, why do they choose to follow the standards that they 
do? While some answers might be inferred from the results of studies examining the benefits of reporting choices, the greatest insights would be obtained through studies that involve direct engagement with managers.

Finally, one of the most striking findings of the study reported in this paper has been the apparent total lack of any published educational research in this domain. While the study certainly did not entail an examination of all outlets that may have published educational papers regarding CSR reports and reporting, the accounting education journals that were selected for examination-Issues in Accounting Education, and Advances in Accounting Education-are two of the leading academic accounting education outlets. Given the growing number of companies issuing and seeking assurance on CSR reports, it appears likely that many accounting students will encounter the preparation, assurance, and interpretation of CSR reports during their careers. Therefore, there appear to be significant opportunities for a variety of scholarship in this area. Of particular value may be case studies and other instructional materials that could be utilized in teaching students about CSR reporting and assurance.

The voluntary issuance of CSR reports and assurance reports thereon has increased substantially in recent years. Further, it appears that increased attention from at least two related groups-investors and the SEC-may foster additional growth in, and perhaps reshaping of this activity. The SEC issued a Concept Release in April 2016 asking for feedback on a broad range of issues related to disclosures under Regulation S-K (SEC, 2016). Preliminary analysis of the 227 total letters received indicated that approximately two-thirds commented on sustainability disclosures, despite the fact that only 11 of the 341 pages in the Concept Release were related to sustainability (SASB, 2016). The responses received indicate that there is significant interest in CSR disclosures, but that there is significant dissatisfaction with what is presently being disclosed. One source summarized the findings as follows: "there is an emerging understanding among investors that corporate ESG [Environmental, 


\section{The BRC Academy Journal of Business Vol. 7, No. 1}

Social, and Governance] information can be important in their investing decisions, and that the current patchwork of ESG reporting methods does not make such information readily accessible" (Lexology, 2016). This same outlet suggested that it is likely that the SEC will introduce some additional standards regarding sustainability reporting in the not-toodistant future (Lexology, 2016). These findings and interpretations are similar to those reported by $\mathrm{PwC}$ indicating great interest in sustainability reporting among investors, but dissatisfaction with both the current reports and a low level of confidence in the results ( $\mathrm{PwC}, 2016 \mathrm{~b})$. Another $\mathrm{PwC}$ report summed up the needs as follows:

The challenge for companies? The determination of which sustainability metrics are material and decision-useful to their stakeholders, and then the implementation of appropriate processes, systems, and controls to produce them reliably. (PwC, 2016a, p. 4)

Accounting scholars have much of value to contribute in addressing this challenge, and it appears that the current literature has only begun to scratch the surface.

\section{REFERENCES}

Borkowksi, Susan C., Mary Jeanne Welsh, and Kristin Wentzel. 2010. "Johnson \& Johnson: A Model for Sustainability Reporting." Strategic Finance. September, pp. 29-37.

Brown-Liburd, Helen, and Valentina L. Zamora. 2015. "The Role of Corporate Social Responsibility Assurance in Investors' Judgments When Managerial Pay is Explicitly Tied to CSR Performance." Auditing: A fournal of Practice \& Theory. February, pp. 75-96. http:// dx.doi.org/10.2308/ajpt-50813

Busco, Cristiano, Mark L. Frigo, Paolo Quattrone, and Angelo Riccaboni. 2014. "Leading Practices in Integrated Reporting." Strategic Finance. September, pp. 23-32. 
Casey, Ryan J., and Jonathon H. Grenier. 2015. "Understanding and Contributing to the Enigma of Corporate Social Responsibility (CSR) Assurance in the United States." Auditing: A fournal of Practice \& Theory. February, pp. 97-130. http://dx.doi.org/10.2308/ajpt-50736

Cheng, Mandy M., Wendy J. Green, and John Chi Wa Ko. 2015. "The Impact of Strategic Relevance and Assurance of Sustainability Indicators on Investors' Decisions." Auditing: A fournal of Practice \& Theory, February, pp. 131-162. http://dx.doi.org/10.2308/ajpt-50738

Cho, Charles H., Robin W. Roberts, and Dennis M. Patten. 2010. "The language of US corporate environmental disclosure." Accounting, Organizations and Society. May, pp. 431-443. http://dx.doi.org/10.10 16/j.aos.2009.10.002

Cho, Charles H., Ronald P. Guidry, Amy M. Hageman, Dennis M. Patten, 2012. "Do actions speak louder than words? An empirical investigation of corporate environmental reputation.” Accounting, Organizations and Society. January, pp. 14-25. http://dx.doi.org/10.1016/j.aos.2011 .12 .001

Cohen, Jeffrey R., and Roger Simnett. 2015a. "A Forum on CSR and Assurance Services." Auditing: A fournal of Practice \& Theory. February, $\mathrm{p}$ vii.

Cohen, Jeffrey R., and Roger Simnett. 2015b. "CSR and Assurance Services: A Research Agenda." Auditing: A Journal of Practice \& Theory. February, pp. 59-74. http://dx.doi.org/10.2308/ajpt-50876

Contrafatto, Massimo. 2014. "The institutionalization of social and environmental reporting: An Italian narrative." Accounting, Organizations and Society, August, pp. 414-432. http://dx.doi.org/10 .1016/j.aos.2014.01.002

Dhaliwal, Dan S., Oliver Zhen Li, Albert Tsang, and Yong George Yang. 2011. "Voluntary Nonfinancial Disclosure and the Cost of Equity Capital: The Initiation of Corporate Social Responsibility Reporting." The Accounting Review. Vol. 86, No. 1, pp. 59-100. http://dx.doi.org/ 10.2308/accr.00000005

Dhaliwal, Dan S., Suresh Radhakrishnan, Albert Tsang, and Yong George Yang. 2012. "Nonfinancial Disclosure and Analyst Forecast Accuracy: 
94 The BRC Academy Journal of Business Vol. 7, No. 1

International Evidence on Corporate Social Responsibility Disclosure." The Accounting Review. Vol. 87, No. 3, pp. 723-759. http://dx.doi.org/ 10.2308/accr-10218

Dzinkowski, Ramonda. 2015. "What's Next For Corporate Reporting?" Strategic Finance. October, pp. 40-45.

Eccles, Robert G., Robert H. Herz, E. Mary Keegan, David M. H. Phillips. 2001. The ValueReporting Revolution. Wiley.

Eccles, Robert G., and Michael P. Krzus. 2011. One Report: Integrated Reporting for a Sustainable Strategy. Wiley.

Eccles, Robert G., and Michael P. Krzus. 2015. The Integrated Reporting Movement. Wiley.

Elliott, W. Brooke, Kevin E. Jackson, Mark E. Peecher, and Brian J. White. 2014. "The Unintended Effect of Corporate Social Responsibility Performance on Investors' Estimates of Fundamental Value." The Accounting Review. Vol. 89, No. 1, pp. 275-302. http://dx.doi.org/10 $.2308 /$ accr-50577

Fornaro, James M. 2011. "SEC Guidance on Disclosure Related to Climate Change." Journal of Accountancy. January, pp. 42-47.

Gao, Feng, Ling Lei Lisic, and Ivy Xiying Zhang. 2014. "Commitment to Social Good and Insider Trading." Fournal of Accounting and Economics. April/May, pp. 149-175. http://dx.doi.org/10.1016/j.jacceco.2014.03.001

Huang, Xiaobei "Beryl," and Luke Watson. 2015. "Corporate Social Responsibility Research in Accounting." Journal of Accounting Literature. Vol. 34, pp. 1-16. http://dx.doi.org/10.1016/j.acclit.2015.0 3.001

IIRC. 2016. Integrated Reporting <IR>. www.integratedreporting.org. March 31, 2016

KPMG International. 2013. The KPMG Survey of Corporate Responsibility Reporting 2013: Executive Summary.

Kim, Yongtae, Myung Seok Park, and Benson Wier. 2012. "Is Earnings Quality Associated with Corporate Social Responsibility?" The Accounting Review. Vol. 87, No. 3, pp. 761-796. http://dx.doi.org/10 $.2308 /$ accr-10209 
Lexology. 2016. The SEC Revisits Sustainability: Will Sustainability Reporting Become Mandatory for Publicly-Traded U.S. Corporations. http://www.lexology.com/library/detail.aspx?g=8148a821-b3d0-4e23 -b7de-55b06f9ed7da. Accessed 1/10/17.

Lynch, Nicholas C. 2013. "The Assurance Market for Sustainability Reporting." Journal of Accountancy. May, p. 35.

Lys, Thomas, James P. Naughton, Clare Wang. 2015. "Signaling through corporate accountability reporting." Fournal of Accounting and Economics, August, pp. 56-72. http://dx.doi.org/10.1016/j.jacceco.20 15.03.001

Monterio, Brad J. 2010a. "Sustainability Reporting and XBRL-Part 1." Strategic Finance. August, pp. 56-58.

Monterio, Brad J. 2010b. "Sustainability Reporting and XBRL-Part 2." Strategic Finance. September, pp. 56-61.

Monterio, Brad J. 2013. "Integrated Reporting and the Potential Role of XBRL.” Strategic Finance. June, pp. 62-65.

Monterio, Brad J. 2014. "Integrated Reporting and Corporate Disclosure." Strategic Finance. March, pp. 54-57.

Monterio, Brad J. 2015. "Integrated Reporting: A Chat with the Experts." Strategic Finance. February, pp. 35-39.

Moser, Donald V., and Patrick R. Martin. 2012. "A Broader Perspective on Corporate Social Responsibility Research in Accounting." The Accounting Review. Vol. 87, No. 3, pp. 797-806. http://dx.doi.org/10 $.2308 /$ accr- 10257

O’Dwyer, Brendan, David Owen, and Jeffrey Unerman. 2011. "Seeking legitimacy for new assurance forms: The case of assurance on sustainability reporting." Accounting, Organizations and Society. January, pp. 31-52. http://dx.doi.org/10.1016/j.aos.2011.01.002

Peters, Gary F., and Andrea M. Romi. 2015. "The Association between Governance Characteristics and the Assurance of Corporate Sustainability Reports." Auditing: A fournal of Practice \& Theory. February, pp. 163-198. http://dx.doi.org/10.2308/ajpt-50849 
Pflugrath, Gary, Peter Roebuck, and Roger Simnett. 2011. "Impact of Assurance and Assurer's Professional Affiliation on Financial Analysts' Assessment of Corporate Social Responsibility Information." Auditing: A fournal of Practice \& Theory. Vol. 30, No. 3, pp. 239-254. http://dx.doi.org/10.2308/ajpt-10047

PwC. 2010. CSR Trends 2010.

PwC. 2016a. Sustainability reporting and disclosure: What does the future look like? July.

PwC. 2016b. Investors, corporates, and ESG: bridging the gap. October.

Ramanna, Karthik. 2013. "A Framework for Research on Corporate Accountability Reporting.” Accounting Horizons. Vol. 27, No. 2, pp. 409-432. http://dx.doi.org/10.2308/acch-50412

SASB. 2016. "SASB Issues Provisional Sustainability Accounting Standards for Infrastructure Sector." March 30, 2016. www.sasb.org.

Savitz, Andrew W., and Karl Weber. 2006. The Triple Bottom Line: How Today's Best-Run Companies Are Achieving Economic, Social and Environmental Success-And How You Can Too. Jossey-Bass.

SEC. 2016. Concept Release: Business and Financial Disclosures Required by Regulation S-K.

Sheehy, Benedict. 2015. "Defining CSR: Problems and Solutions." fournal of Business Ethics. 131, pp. 625-648. http://dx.doi.org/10.1007/s1055 1-014-2281-x

Thomas, Harrison. 2015. "Sustainability Reporting." Strategic Finance. October, pp. 23-24.

Tregida, Helen, Markus Milne, Kate Kearins. 2014. "(Re)presenting 'sustainable organizations.' Accounting, Organizations and Society. August, pp. 477-494. http://dx.doi.org/10.1016/j.aos.2013.10.006

Unerman, Jeffrey, and Christopher Chapman. 2014. "Academic contributions to enhancing accounting for sustainable development." Accounting, Organizations and Society, August, pp. 385-394. http:// dx.doi.org/10.1016/j.aos.2014.07.003

Verschoor, Curtis C. 2012, "Responsibility Reporting is Getting More Attention.” Strategic Finance. December, pp. 13-15. 
Verschoor, Curtis C. 2014. "Integrated Reporting Lags in the U.S." Strategic Finance. December, pp. 13, 14, 61.

\section{Citation Information}

Fischer, Michael J., and Carol M. Fischer. "Corporate Social Responsibility Reports: A Review of the Recent Accounting Literature." The BRC Academy Journal of Business 7, no. 1 (2017): 73-98. http:// dx.doi.org/10.15239/j.brcacadjb.2017.07.01.ja04

\section{Web Appendix}

A web appendix for this paper is available at:

http://dx.doi.org/10.15239/j.brcacadjb.2017.07.01.wa04 
98 The BRC Academy Journal of Business Vol. 7, No. 1

\section{Notes}

1. A summary of the various acronyms used throughout this paper is provided as Figure 1.

2. A variety of terms are used to describe this type of reporting; e.g., responsibility reporting; sustainability reporting; environmental, social, and governance (ESG) reporting; and environmental reporting. Also, the developing area of integrated reporting includes and extends the concept of CSR reporting. Articles covering all of these types of reporting were included in this review. The terms "Corporate Social Responsibility" and "CSR" are used in the paper to refer to all these types of reporting. 